\title{
Impact of soil applied humic acid, zinc and boron supplementation on the growth, yield and zinc translocation in wheat
}

\author{
Maqsood ul Hussan ${ }^{1}$, Muhammad Farrukh Saleem ${ }^{1}$, Muhammad Bilal Hafeez ${ }^{1}$, Shahbaz Khan ${ }^{*}$, \\ Sadam Hussain², Naeem Ahmad², Yasir Ramzan³ ${ }^{3}$ Majid Nadeem³ \\ ${ }^{1}$ Department of Agronomy, University of Agriculture, Faisalabad, Pakistan \\ ${ }^{2}$ Department of Agronomy, Northwest A\&F University, Yangling, China \\ ${ }^{3}$ Wheat Research Institute, Ayub Agricultural Research Institute, Faisalabad, Pakistan
}

\section{Received:}

March 08, 2021

Accepted:

May 25, 2021

Online First:

November 03, 2021

Published:

January 09, 2022

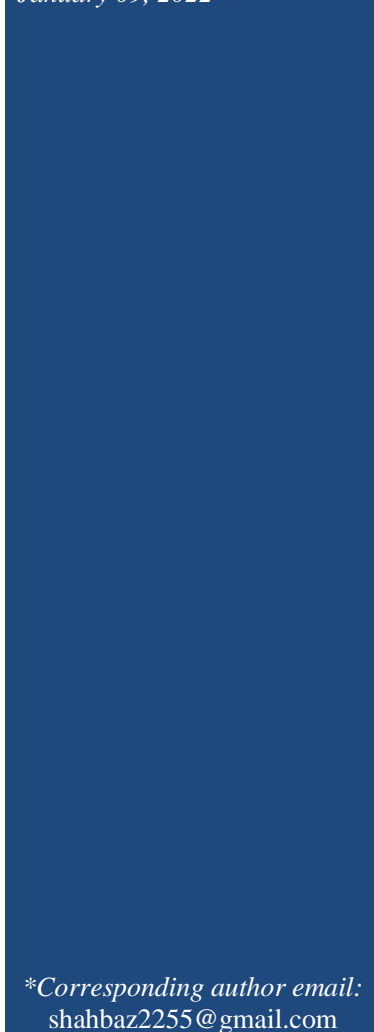

\section{Abstract}

The experiment was conducted to optimize the level of humic acid, zinc and boron for better growth, enhanced yield and grain quality of wheat crop cultivated under field condition. Growth characteristics, yield and its components, and zinc concentrations in straw and grain were analyzed under two application rate of humic acid $\left(0\right.$ and $\left.10 \mathrm{~kg} \mathrm{ha}^{-1}\right)$, three level of boron $\left(\mathrm{B}_{0}=0, \mathrm{~B}_{1=} 2\right.$ and $\left.\mathrm{B}_{2}=4 \mathrm{~kg} \mathrm{ha}^{-1}\right)$ and zinc $\left(\mathrm{Zn}_{0}=0, \mathrm{Zn}_{1}=5\right.$ and $\left.\mathrm{Zn}_{2}=10 \mathrm{~kg} \mathrm{ha}^{-1}\right)$. Results revealed that application of $\mathrm{Zn}$ at $10 \mathrm{~kg}$ $\mathrm{ha}^{-1}$ and $\mathrm{B}$ at $4 \mathrm{~kg} \mathrm{ha}^{-1}$ combine with humic acid $\left(10 \mathrm{~kg} \mathrm{ha}^{-1}\right)$ significantly increased yield and its components (except flag leaf area under humic acid application), and $\mathrm{Zn}$ contents in straw. The maximum plant height, spike length and grain filling rate were recorded at $\mathrm{Zn}_{2}$ and $\mathrm{B}_{2}$ with humic acid application. Maximum grain yield was produced for $\mathrm{Zn}_{2}$ and $\mathrm{B}_{2}$ under humic acid application, which was associated with higher 1000-grain weight and biological yield. Maximum biological and straw yields were produced by application of $\mathrm{Zn}_{2}$ and $\mathrm{B}_{2}$ under humic acid fertilization. Maximum $\mathrm{Zn}$ contents in straw have been recorded for $\mathrm{Zn}_{2}$ and $\mathrm{B}_{2}$ under humic acid application, while maximum values of crude protein and $\mathrm{Zn}$ contents in $\mathrm{Zn}_{2}$ and $\mathrm{B}_{2}$ were statically same with $\mathrm{Zn}_{1}$ and $\mathrm{B}_{1}$ under humic acid application. Furthermore, the highest boron contents in grain were recorded for $\mathrm{Zn}_{2}$ and $\mathrm{B}_{2}$, and these values were statistically same with $\mathrm{Zn}_{2}$ and $\mathrm{B}_{1}$ under humic acid application. It is concluded that application of $\mathrm{Zn}_{2}$ and $\mathrm{B}_{2}$ in combination with humic acid could be a good agronomic practice to enhance the zinc content in straw and grain yield of wheat crop.

Keywords: Micronutrients, Productivity, Crude protein, Grain quality, Wheat straw

\section{How to cite this:}

Hussan MU, Saleem MF, Hafeez MB, Khan S, Hussain S, Ahmad N, Ramzan Y and Nadeem M, 2022. Impact of soil applied humic acid, zinc and boron supplementation on the growth, yield and zinc translocation in wheat. Asian J. Agric. Biol. 2022(1): 202102080. DOI: https://doi.org/10.35495/ajab.2021.02.080

This is an Open Access article distributed under the terms of the Creative Commons Attribution 3.0 License. (https://creativecommons.org/licenses/by/3.0), which permits unrestricted use, distribution, and reproduction in any medium, provided the original work is properly cited. 


\section{Introduction}

The demand of agricultural products is increasing day by day because of uncontrolled increasing trends of world population. To feed the increasing population, the production of edible crops should be increased. Wheat (Triticum aestivum L.), a major staple grain, provides a basic source of protein and calories for humans on the global scale. Although, agronomists have achieved the highest yield from last few years, however, average yield of wheat is too low, because of inadequate nutrition for crop (Kosina et al., 2007). Micronutrients deficiencies have gained more concern in recent years, and various researchers reports as a major problem in south Asian countries, where rice-wheat cropping system (RWCS) exists (Johnson et al., 2005). Chemical composition of grains, particularly micronutrients are significantly affected under various growing environments (Akcura et al., 2019).

Zinc $(\mathrm{Zn})$ deficiency in soil is responsible for the reduction in yield as well as nutritional value of cereal crops especially wheat. It is estimated that $50 \%$ of cereals around the globe are produced in $\mathrm{Zn}$ deficit soils, and this topic has been achieved great attention in last two decades because of widespread inadequacy of $\mathrm{Zn}$ in plants and humans as well. The quantity of $\mathrm{Zn}$ up to $40 \mathrm{mg} \mathrm{kg}^{-1}$ in cereals' grain is recommended as nutritional requirement for a human body (Cakmak et al., 2010). Low concentration of $\mathrm{Zn}$ in cereals' grain causes health hazards for human beings in developing countries, where cereal crops are playing vital role to compensate their daily needs. The microelements play major roles in physiological as well as in biochemical process, and regulate the growth and development, protein synthesis, photosynthetic processes and antioxidant defense system in plants (Hafeez and Saleem, 2013). Ramzan et al. (2020) also reported that application of micronutrients, specifically $\mathrm{Fe}$ and $\mathrm{Zn}$, is very promising to improve the productivity and grain quality of wheat crop.

Plant requires optimal quantities of boron for better growth and development. However, according to an estimation, $49 \%$ of arable land in Pakistan and 31\% on the global scale are deficient in boron (Rashid et al., 2004). Boron (B), an essential micronutrient, affects the several biological process in plants including synthesis of cell wall, carbohydrate and nucleic acid metabolism, elongation of cell wall and translocation of assimilates (Herrera-Rodriguez et al.,
2010). B supply has no direct-effect on photosynthetic activities, however, it increases the net photosynthetic rates by harvesting different plant pigments such as carotenes and chlorophyll in plants leaves (Ganie et al., 2013). Application of B is responsible to improve the growth of field crops (Khan et al., 2016). Moreover, disrupting cell wall structure, diminished the progress of proton pump ATPase, decreased photosynthetic productivity, and electron transport chain is associated with deficiency of B (Marschener, 1995; Rehman et al., 2018).

Humic substances are produced as a result of chemical and biological degradation of remaining of plants and animals, and provide a major source of organic carbon in the soil. Most prominent biostimulant is humic acid (HA), which has direct and indirect effects on morpho-physiological growth of plants (Peña-Méndez et al., 2005). HA is mainly derived from humic substances and finally decomposed material contains $60 \%$ of organic matter in soil (Muscolo et al., 2013). On other hands, HA application to the soil not only improves the various soil properties (such as structure stability, biological activity and effecting soil $\mathrm{PH}$ ), but also results in better roots development, improve water holding capacity, carbon sequestration, cation exchange capacity, and upgrade the availability of nutrients from rhizosphere (Gümüş and Şeker, 2015). The application of HA in combination of fulvic acid can improve the seed stand establishment, and increase the availability of some macro and micronutrients (such as $\mathrm{Zn}, \mathrm{Fe}, \mathrm{Cu}$ and $\mathrm{Mn}$ ) from rhizosphere to plants (Sharif et al., 2002).

Considerable number of studies have been conducted to explore the impact of $\mathrm{B}$ and $\mathrm{Zn}$ supplementation on the growth and productivity of wheat. However, not a single study has been found to evaluate the combine effects of $\mathrm{B}$ and $\mathrm{Zn}$ with HA application on performance of wheat, when applied to the soil. Therefore, in this study we focused on soil applied B and $\mathrm{Zn}$ with humic acid application, and studied their effects on the grain quality, productivity, and concentrations of $\mathrm{B}$ and $\mathrm{Zn}$ in wheat-grain under field condition. We also evaluated the best levels of $\mathrm{B}$ and Zn under humic acid treatments, by studying the growth, yield and quality attributes of wheat crop.

\section{Material and Methods}

\section{Site description}

One-year field study was conducted at the 
Agronomic Research Area, University of Agriculture Faisalabad-Pakistan during 2016-17 cropping year. The seeds of wheat (Triticum aestivum L. cv. Galaxy13) were purchased from Wheat Research Institute (WRI), AARI, Faisalabad, Pakistan. The meteorological data were recorded at latitude $31^{\circ} \mathrm{N}$, longitude $73^{\circ} \mathrm{E}$ and altitude of $184.4 \mathrm{~m}$ at meteorological observatory cell established at the university. The average relative humidity $54.15 \%$, temperature $19.36^{\circ} \mathrm{C}$ and average rainfall $10.01 \mathrm{~mm}$ were recorded during the growth period (November 2016 to April 2017). The physico-chemical properties of experimental soil (George et al., 2013) were as fellow: organic matter $0.81 \%$. electrical conductivity $1.38 \mathrm{dS} \mathrm{m} \mathrm{m}^{-1}, \mathrm{pH}$ 8.2, total nitrogen $(\mathrm{N})$ 0.09\%, phosphorus contents $(\mathrm{P}) 8.1 \mathrm{ppm}$, potassium contents (K) $200 \mathrm{ppm}$, hot water-soluble boron (B) $0.35 \mathrm{mg}$ $\mathrm{kg}^{-1}$, DTPA- Extractable zinc (Zn) $0.45 \mathrm{mg} \mathrm{kg}^{-1}$.

\section{Experimental details}

The study involved a randomized complete block design with factorial arrangement, and having three replications for each treatment. The area of plot was $10.8 \mathrm{~m}^{-2}(1.8 \mathrm{~m} \times 6 \mathrm{~m})$. The experiment was consisted on two HA levels; $\mathrm{H}_{0}=\left(\right.$ Control; $\left.0 \mathrm{~kg} \mathrm{ha}^{-1}\right)$ and $\mathrm{H}_{1}=$ $\left(10 \mathrm{~kg} \mathrm{ha}^{-1}\right)$, three level of boron $\left(\mathrm{B}_{0=} 0, \mathrm{~B}_{1=} 2\right.$ and $\mathrm{B}_{2}$ $\left.=4 \mathrm{~kg} \mathrm{ha}^{-1}\right)$ and zinc $\left(\mathrm{Zn}_{0}=0, \mathrm{Zn}_{1}=5\right.$ and $\mathrm{Zn}_{2}=10 \mathrm{~kg}$ $\mathrm{ha}^{-1}$ ) under field condition. The $\mathrm{Zn}, \mathrm{B}$ and $\mathrm{HA}$ were applied into the soil by using $\mathrm{ZnSO}_{4} .7 \mathrm{H}_{2} \mathrm{O}, \mathrm{H}_{3} \mathrm{BO}_{3}$ and potassium-humate respectively. All the quantity of these nutrients were applied as side dressing at time of sowing.

\section{Crop husbandry}

Field plowing was done twice and followed by planking. The seeds were sown on November 20, 2016 with hand drill with a distance of $22.5 \mathrm{~cm}$ among the rows. The seed rate was kept at $120 \mathrm{~kg} \mathrm{ha}^{-}$ 1. At the time of sowing, one-third of $N\left(120 \mathrm{~kg} \mathrm{ha}^{-1}\right.$ urea), all dose of $\mathrm{P}$ (diammonium phosphate, $80 \mathrm{~kg}$ $\mathrm{ha}^{-1}$ ) and total $\mathrm{K}$ (murate of potash $60 \mathrm{~kg} \mathrm{ha}^{-1}$ ) were applied to each experimental unit. Remaining doses of nitrogen were applied in two equal splits; first at 25 days after sowing (DAS) and last with second irrigation (80 DAS). During the growth period, five numbers of irrigations were applied.

\section{Observations and measurements}

For the estimation of grain filling rate $\left(\mathrm{g} \mathrm{day}^{-1}\right)$, ten spikes were harvested randomly from each plot before and after anthesis, and placed them into oven to get constant weight. The interval for collecting spikes was 15 days. Then grain filling rate was determined with following formula;

$$
\text { Grain filling rate }=\frac{\mathrm{W} 2-\mathrm{W} 1}{\mathrm{~T} 2-\mathrm{T} 1} \times 100
$$

Here, $\mathrm{W}_{1}$ and $\mathrm{W}_{2}$ denote first and second interval dry weight respectively, while $T_{1}$ and $T_{2}$ are time durations for first and second interval respectively.

At the milking stage, 10 plants from each experimental unit were taken to measure the flag leaf length. At maturity, 10 plants from each plot were selected randomly for measurement of plant height and spike length as well. Plant heights $(\mathrm{cm})$ and spike lengths $(\mathrm{cm})$ were measured by using a meter rod. After harvesting, wheat plants were tied into bundles and sun-dried for one week. The biological yield was recorded by using a spring balance while grain yield was noted by using an electronic balance. From each plot, 1000 grains were manually counted, and their weight was determined with an electronic balance. The wet-digestion protocol was followed for the estimation of $\mathrm{Zn}$ contents in straw and grains (Rashid, 1986). Boron contents in the grains were estimated by dry ash (Chapman and Pratt, 1961), and subsequent estimation was done by colorimetry using Azomethine-H (Bingham, 1982). The crude protein contents (\%) were determined by Gunning and Hibbard method using $\mathrm{H}_{2} \mathrm{SO}_{4}$ for digestion followed by distillation of $\mathrm{NH}_{3}$ in boric acid with the help of Kjeldhal apparatus (Jackson, 1960).

\section{Statistical analysis}

Collected data were analyzed statistically according to the ANOVA (analysis of variance) technique proposed by Fisher. Tuckey's HSD test was followed to observe the statistical differences among the variance and means of treatments (Steel et al., 1997).

\section{Results}

The plant height was significantly different under HA application and $\mathrm{Zn}$ and $\mathrm{B}$ treatments (Figure 1). The interaction between $\mathrm{Zn}, \mathrm{B}$ and $\mathrm{HA}$ rates was also found significant. The maximum values of plant height $(115.7 \mathrm{~cm})$ were recorded under HA with $\mathrm{Zn}$ and $\mathrm{B}$ (10 and $4 \mathrm{~kg} \mathrm{ha}^{-1}$ ) application. The minimum plant height was recorded when $\mathrm{Zn}$ and $\mathrm{B}$ was applied at 5 and $0 \mathrm{~kg} \mathrm{ha}^{-1}$, respectively. A similar trend was also observed for $\mathrm{Zn}_{0}, \mathrm{~B}_{1}, \mathrm{~B}_{0}$ and $\mathrm{Zn}_{1}$ under 
with and without HA application. Likewise, the highest value of spike length $(17.5 \mathrm{~cm})$ was observed for $\mathrm{Zn}_{2}$ and $\mathrm{B}_{2}$ under with and without $\mathrm{HA}$ application, the value was statistically at par with $B_{1}$ and $\mathrm{Zn}_{1}$. The minimum value was recorded in $\mathrm{B}_{0}$ and $\mathrm{Zn}_{1}$ under with and without HA application. The application of $\mathrm{Zn}$ and $\mathrm{B}$ had a significant effect on flag leaf area (FLA), however, HA application and their interaction showed non-significant effect on FLA (Figure 1). Maximum grain filling rate $(0.05 \mathrm{~g}$ day $^{-1}$ ) was recorded under micronutrient treatment with $\mathrm{Zn}_{2}$ and $\mathrm{B}_{2}$ under $\mathrm{HA}$ application, which was statistically same with $\mathrm{Zn}_{1}, \mathrm{~B}_{0}$ and $\mathrm{B}_{1}$.
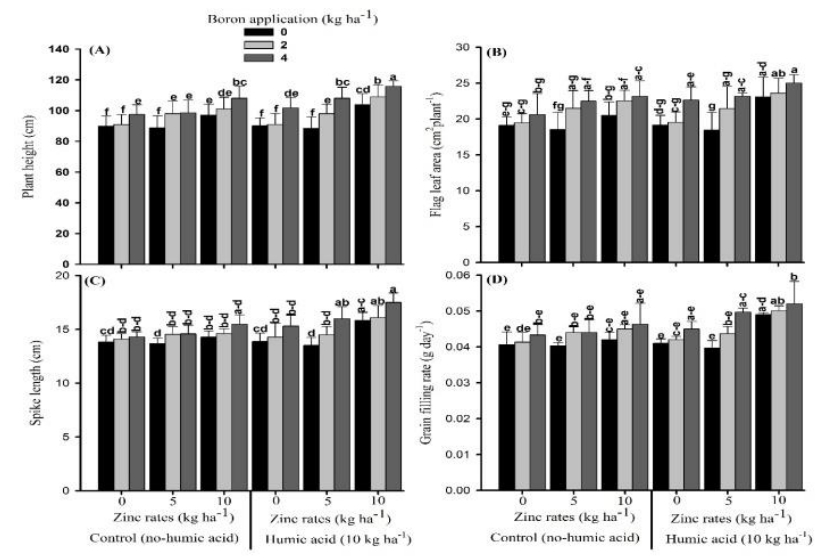

Figure-1: Plant height (A), flag leaf area (B), spike length $(C)$, and grain filling rate $(D)$ under two application rate of humic acid $\left(0 \mathrm{~kg} \mathrm{ha}^{-1}\right.$ (control) and $\left.10 \mathrm{~kg} \mathrm{ha}^{-1}\right)$ ), three level of boron $\left(B_{0}=0, B_{1=} 2\right.$ and $\left.B_{2}=4 \mathrm{~kg} \mathrm{ha}^{-1}\right)$ and $\operatorname{zinc}\left(\mathrm{Zn}_{0}=0, \mathrm{Zn}_{1}=5\right.$ and $\left.\mathrm{Zn}_{2}=10 \mathrm{~kg} \mathrm{ha}^{-1}\right)$. Above bars, same alphabet are non-significant at $5 \%$ level of significance.

There were significant effects of $\mathrm{Zn}$ and $\mathrm{B}$ and HA application, and their interaction on biological yield, straw yield, 1000-grain weight and grain yield in winter wheat (Figure 2). Among all the treatments, $\mathrm{Zn}_{2}$ and $\mathrm{B}_{2}$ produced the highest biological yield of 15ton ha $^{-1}$ under HA application (Figure 2). The minimum biological yield was recorded in $\mathrm{B}_{0}$ and $\mathrm{Zn}_{0}$ that was followed by $\mathrm{B}_{0}$ under $\mathrm{Zn}_{1}$. The maximum straw yield was recorded under $\mathrm{Zn}_{2}$ and $\mathrm{B}_{2}$, under $\mathrm{HA}$ fertilization, and it was statistically same with $\mathrm{Zn}_{2}$ under $\mathrm{B}_{1}$, and $\mathrm{Zn}_{1}$ under $\mathrm{B}_{2}$ (Figure 2). Minimum yield of straw (4.96 kg ha ${ }^{-1}$ ) was recorded in $\mathrm{Zn}_{1}$ and $\mathrm{B}_{0}$. The highest 1000-grain weight (39.3 g) was noted under $\mathrm{Zn}_{2}$ and $\mathrm{B}_{2}$ with HA application (Figure 2). The lowest 1000-grain weight (33.06 g) was noted in $\mathrm{Zn}_{1}$ and $\mathrm{B}_{0}$ followed by $\mathrm{Zn}_{0}$ with $\mathrm{B}_{1}$, and $\mathrm{Zn}_{0}$ with $\mathrm{B}_{0}$. The application of HA with maximum dose of $\mathrm{Zn}$ and $\mathrm{B}$ were resulted in highest grain yield (5.2tons ha ${ }^{-1}$ ) (Figure 2). The treatment of $\mathrm{Zn}$ and $\mathrm{B}\left(\mathrm{Zn}_{1}\right.$ and $\left.\mathrm{B}_{0}\right)$ showed the lowest grain yield (3.5tons $\left.\mathrm{ha}^{-1}\right)$, that was not differ significantly with control, $\mathrm{Zn}_{0}$ under $\mathrm{B}_{1}$, and $\mathrm{Zn}_{2}$ with $\mathrm{B}_{0}$.

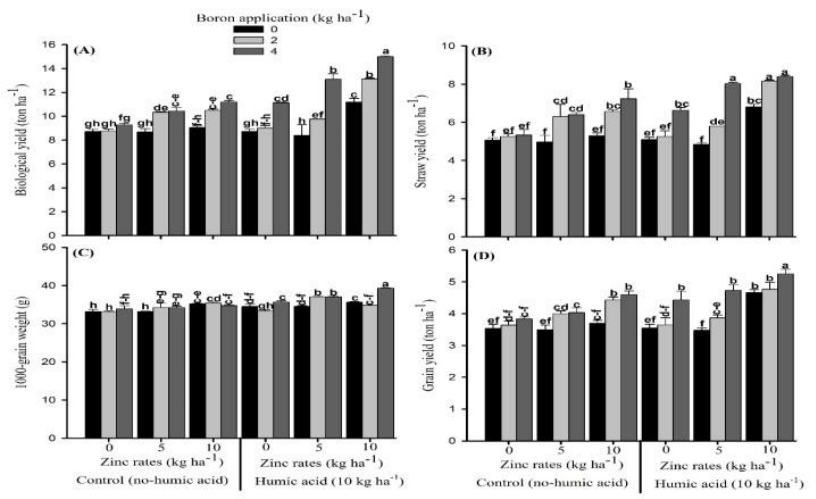

Figure-2: Biological yield (A), straw yield (B), 1000-grain weight $(C)$, and grain yield (D) of wheat under two application rate of humic acid (0 $\mathrm{kg} \mathrm{ha}^{-1}$ (control) and $\left.10 \mathrm{~kg} \mathrm{ha}^{-1}\right)$ ), three level of boron $\left(B_{0}=0, B_{1}=2\right.$ and $\left.B_{2}=4 \mathrm{~kg} \mathrm{ha}^{-1}\right)$ and zinc $\left(\mathbf{Z n}_{0}=0, \mathbf{Z n}_{1}=5\right.$ and $\left.\mathbf{Z n}_{2}=10 \mathrm{~kg} \mathrm{ha}^{-1}\right)$. Above bars, same alphabet is non-significant at $5 \%$ level of significance.

The effects of $\mathrm{Zn}$ and B and HA application and their interaction were recorded to be significant for quality parameters at $5 \%$ probability level (Table 1 ). The $\mathrm{Zn}$ contents in straw $\left(40.5 \mu \mathrm{g} \mathrm{g}^{-1}\right)$ were observed higher with $\mathrm{Zn}_{2}$ and $\mathrm{B}_{2}$ under $\mathrm{HA}$ application, while, the minimum were recorded for $\mathrm{Zn}_{1}$ and $\mathrm{B}_{0}$ under with and without application of $\mathrm{HA}$, followed by $\mathrm{Zn}_{0}$ and $\mathrm{B}_{1}$. The highest $\mathrm{Zn}$ contents in grain $\left(46.3 \mu \mathrm{g} \mathrm{g}^{-1}\right)$ were found for $\mathrm{Zn}_{2}$ and $\mathrm{B}_{2}$ under the application of HA followed by $Z_{2}$ under $B_{1}$, and $Z_{1}$ under $B_{2}$ application (Figure 3). The minimum grain $\mathrm{Zn}$ contents $\left(19.3 \mu \mathrm{g} \mathrm{g}^{-1}\right)$ were found in $\mathrm{Zn}_{1}$ and $\mathrm{B}_{0}$ which was statistically at par with $\mathrm{Zn}_{0}$ under $\mathrm{B}_{0}$ and $\mathrm{B}_{1}$ with and without $\mathrm{HA}$ application. The highest grain crude protein $\left(12.1 \%\right.$ ) was recorded under $\mathrm{Zn}_{2}$ and $\mathrm{B}_{2}$ with $\mathrm{HA}$ application followed by $\mathrm{Zn}_{1}$ under $\mathrm{B}_{2}$, and $\mathrm{Zn}_{2}$ under $\mathrm{B}_{1}$ and $\mathrm{B}_{0}$ (Figure 3). The application of $\mathrm{HA}$ with $\mathrm{Zn}_{2}$ and $\mathrm{B}_{2}$ produced the maximum $B$ content in grain $\left(3.16 \mu \mathrm{g} \mathrm{g}^{-1}\right)$ which was statistically same with $\mathrm{Zn}_{2}$ under $\mathrm{B}_{1}$. 
Maqsood ul Hussan et al.

Table-1: Analysis of variance for growth, yield contributed attributes and grains quality parameters

\begin{tabular}{|c|c|c|c|c|c|c|}
\hline Traits & $\begin{array}{l}\text { Plant height } \\
\text { (cm) }\end{array}$ & $\begin{array}{c}\text { Flag leaf area } \\
\left(\mathrm{cm}^{2} \text { plant }^{-1}\right)\end{array}$ & $\begin{array}{l}\text { Spike length } \\
\text { (cm) }\end{array}$ & $\begin{array}{c}\text { Grain filling rate } \\
\left(\mathrm{g} \mathrm{day}^{-1}\right)\end{array}$ & $\begin{array}{c}\text { Biological } \\
\text { yield }\left(\mathrm{t} \mathrm{ha}^{-1}\right)\end{array}$ & $\begin{array}{c}\text { Straw yield } \\
\left(\mathrm{t} \mathrm{ha}^{-1}\right)\end{array}$ \\
\hline $\mathrm{Zn}$ & 75.84 *** & $6.97 * *$ & $6.27 * *$ & $5.78 * *$ & $104.86^{* * *}$ & $66.22 * * *$ \\
\hline B & $66.63 * * *$ & $7.21 * *$ & $5.57 * *$ & $4.28^{*}$ & 116.19 *** & $66.65 * * *$ \\
\hline HA & $22.67 * * *$ & $1.92 \mathrm{~ns}$ & $6.15^{*}$ & $4.65^{*}$ & 102.66 *** & $39.18 * * *$ \\
\hline $\mathrm{Zn} \times \mathrm{B}$ & $2.84 *$ & $0.58 \mathrm{~ns}$ & $0.23 \mathrm{~ns}$ & $0.29^{\mathrm{ns}}$ & $6.43 * * *$ & $5.47 * *$ \\
\hline $\mathrm{Zn} \times \mathrm{HA}$ & $4.35^{*}$ & $0.57 \mathrm{~ns}$ & $1.65 \mathrm{~ns}$ & $1.48 \mathrm{~ns}$ & $28.51 * * *$ & 8.60 *** \\
\hline $\mathrm{B} \times \mathrm{HA}$ & $3.51 *$ & $0.26 \mathrm{~ns}$ & $0.96 \mathrm{~ns}$ & $0.37 \mathrm{~ns}$ & $5.19 * * *$ & $7.33 * *$ \\
\hline $\mathrm{Zn} \times \mathrm{B} \times \mathrm{HA}$ & $1.11 \mathrm{~ns}$ & $0.14 \mathrm{~ns}$ & $0.09 \mathrm{~ns}$ & $0.29 \mathrm{~ns}$ & $1.80 \mathrm{~ns}$ & $3.97 * *$ \\
\hline & $\begin{array}{l}\text { 1000-grain weight } \\
(\mathrm{g})\end{array}$ & $\begin{array}{l}\text { Grain yield } \\
\left(\mathrm{t} \mathrm{ha}^{-1}\right)\end{array}$ & $\begin{array}{c}\text { Straw Zn content } \\
\left(\mu \mathrm{g} \mathrm{mg}^{-1}\right)\end{array}$ & $\begin{array}{l}\text { Grain } \mathrm{Zn} \text { content } \\
\left(\mu \mathrm{g} \mathrm{mg}^{-1}\right)\end{array}$ & $\begin{array}{l}\text { Grain crude } \\
\text { protein }(\%)\end{array}$ & $\begin{array}{l}\text { Grain B content } \\
\qquad\left(\mu \mathrm{g} \mathrm{mg}^{-1}\right)\end{array}$ \\
\hline $\mathrm{Zn}$ & $45.87 * * *$ & $63.96 * * *$ & $255.12 * * *$ & $58.94 * * *$ & $28.82 * * *$ & $108.78 * * *$ \\
\hline B & $28.74 * * *$ & $49.98 * * *$ & $310.18 * * *$ & $60.24 * * *$ & $22.44 * * *$ & $119.71 * * *$ \\
\hline HA & $99.43 * * *$ & 32.76 *** & 120.80 *** & $24.83 * * *$ & $23.51 * * *$ & $18.50 * * *$ \\
\hline $\mathrm{Zn} \times \mathrm{B}$ & $8.20 * * *$ & $1.32 \mathrm{~ns}$ & $17.11 * * *$ & $6.97 * * *$ & $1.07 \mathrm{~ns}$ & $15.27 * * *$ \\
\hline $\mathrm{Zn} \times \mathrm{HA}$ & $4.64 *$ & $6.20 *$ & $28.45 * * *$ & $7.70 * *$ & $2.57 \mathrm{~ns}$ & $7.74 * *$ \\
\hline $\mathrm{B} \times \mathrm{HA}$ & $18.59 * * *$ & $7.61 *$ & $19.10 * * *$ & $1.67 \mathrm{~ns}$ & $3.56^{*}$ & $1.85 \mathrm{~ns}$ \\
\hline $\mathrm{Zn} \times \mathrm{B} \times \mathrm{HA}$ & $8.89 * * *$ & $2.49 \mathrm{~ns}$ & $3.27 *$ & $1.04 \mathrm{~ns}$ & $2.08 \mathrm{~ns}$ & $0.86 \mathrm{~ns}$ \\
\hline
\end{tabular}

The values are $\mathrm{F}$-value. $\mathrm{Zn}$, zinc; $\mathrm{B}$, boron; $\mathrm{HA}$, humic acid; ns denotes non-significance at $\mathrm{P}=0.05$; *, **, *** significance at $\mathrm{P}<0.05, \mathrm{P}<0.01, \mathrm{P}<0.001$, respectively

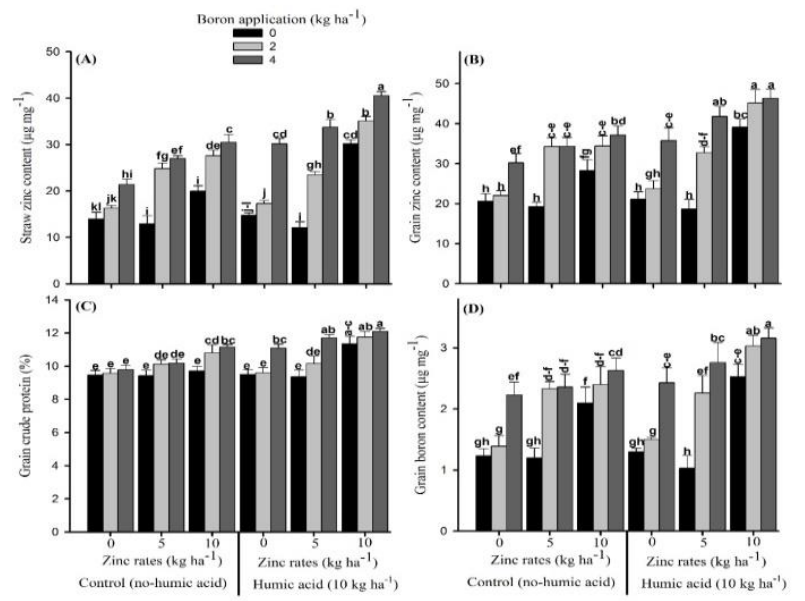

Figure-3: Straw Zn content (A), grain zinc content $(B)$, grain crude protein $(C)$ and grain boron content (D) under two application rate of humic acid $(0 \mathrm{~kg}$ $\mathrm{ha}^{-1}$ (control) and $\left.10 \mathrm{~kg} \mathrm{ha}^{-1}\right)$ ), three level of boron $\left(B_{0}=0, B_{1=} 2\right.$ and $\left.B_{2}=4 \mathrm{~kg} \mathrm{ha}^{-1}\right)$ and zinc $\left(Z_{0}=0, Z_{1}\right.$ $=5$ and $\mathrm{Zn}_{2}=10 \mathrm{~kg} \mathrm{ha}^{-1}$ ). Above bars, same alphabet are non-significant at $5 \%$ level of significance.

\section{Discussion}

The results supported the hypothesis that soil applied $\mathrm{Zn}$ and $\mathrm{B}$ and HA enhanced the crop growth, grain mineral contents and productivity of wheat crop. The increased in plant height, spike length and grain filling rate were significantly influenced by sole and combine application of $\mathrm{Zn}$ and $\mathrm{B}$ and humic acid as well (Table 1). Zinc availability plays a key role during developmental and physiological processes, and the activation of different enzymes, and its deficiency causes severe disorder during physiological processes in plants. Zinc application increases the translocation of photo-assimilate, and improve the indole acetic acid (IAA) metabolism as well (Zeidan et al., 2010). Zinc availability is also crucial for cell division, cell expansion, improve chlorophyll pigments in leaf, increased internode distance and ultimately resulted in increased the plant height. Significant increase in FLA under Zn, B and HA fertilization in our experiment is due to role of $\mathrm{Zn}$ in metabolism of plant hormones like (IAA) and tryptophan (Khan et al., 2006). Zinc is also important for tryptophan, which is prerequisite for IAA production, both the hormones are essential for better leaf growth (Marschener, 1995). The increment in crop growth is due to application of $\mathrm{Zn}$ which activates carbonic anhydrase enzyme. The carbonic anhydrase enzyme consists of $\mathrm{Zn}$ atom, and thus upgrades the absorption and dehydration of $\mathrm{CO}_{2}$ and increases the photosynthesis process and biomass production (Hassan et al., 2019). HA application improves the physical properties (such as microbial activity, water holding capacity) and chemical properties (such cation exchange capacity and nitrogenase activity) of soil (Khattak et al., 2013).

The application of HA can increase the plant height, shoot fresh weight and shoot dry weight up to $10 \%$, 
$25 \%$ and $18 \%$, respectively (Tahir et al., 2011). With increasing the rates of micronutrients and HA application, the increased yield and its parameters were reported in this experiment. The increment in biological yield, 1000-grain weight, straw yield and grain yield were associated with maximum grain per spike, higher 1000-grain weight and maximum spike length under supply of Zn, B and HA. The increased number of grains per spike, more spike length, spikelet per spike and 1000-grain weight under $\mathrm{Zn}$ application were also due to the better cell elongation, cell division and cell enlargement under $\mathrm{Zn}$ treatments (Soleimani, 2006). Zinc is essential for pollen tube formation, fertilization and pollination, and more grain yield under $\mathrm{Zn}$ fertilization was reported elsewhere (Pandey et al., 2006). Boron as essential micronutrient, plays a vital role during reproductive phase of plants, and its accessibility for plant ensures the transfer of assimilate for developing grain, and in this way, grain yield is significantly enhanced (Iqbal et al., 2017; Rehman et al., 2018). The improvement in biological and straw yield under application $\mathrm{Zn}$ and $\mathrm{B}$ was associated with enhancement in morpho-phonological traits of wheat under these treatments. The fertilization of HA with combination of micronutrients enhances the grain and biological yield, spike length, 1000- grain weight of wheat, and these finding are in line with previous study (Radwan et al., 2015). The increment in yield related attributes were due to high photosynthetic activity and stimulation of $\mathrm{N}$ metabolism under HA fertilization (Haghighi et al., 2012).

The results indicated that quantities of $\mathrm{Zn}$ and $\mathrm{B}$ in grains and straw, and crude protein contents in wheat grain were improved by fertilization of micronutrients (Zn and B) under application of HA. The application of $\mathrm{B}$ significantly enhances the $\mathrm{N}$ accumulation in grains, since the role of $\mathrm{B}$ in protein synthesis and nucleic acid metabolism is well understood (Ferdoush and Rahman, 2013). There was a positive correlation between $\mathrm{B}$ availability and protein content, so fertilization with $\mathrm{B}$ can enhance the protein contents $(68-74 \%)$, increase amino acids, and essential minerals in plant (Iqtidar and Rehman, 1984). Identifying the increased $\mathrm{Zn}$ and $\mathrm{B}$ contents in straw and grain is might be due to appropriate supply of microelements to developing grains.

\section{Conclusion}

In conclusion, higher rates of $\mathrm{Zn}$ and $\mathrm{B}$ are beneficial for growth, yield and its attributes, $\mathrm{Zn}$ and B contents in straw and grains as well. Moreover, the application of HA in the soil can also contribute for the higher yields. Application of $\mathrm{B}$ and $\mathrm{Zn}$ at 4 and $10 \mathrm{~kg} \mathrm{ha}^{-1}$ respectively improved the wheat growth, yield and grain quality in combination with HA application at $10 \mathrm{~kg} \mathrm{ha}^{-1}$.

\section{Acknowledgement}

Authors are thankful to Department of Agronomy, University of Agriculture, Faisalabad-Pakistan, for providing the land and other resources to conduct the current experiment.

\section{Disclaimer: None.}

\section{Conflict of Interest: None.}

Source of Funding: None.

\section{References}

Akcura M, Turan V, Kokten K and Kaplan M, 2019. Fatty acid and some micro element compositions of cluster bean (Cyamopsis tetragonoloba) genotype seeds growing under Mediterranean climate. Ind. Crops Pro. 128: 140-146.

Bingham FT, 1982. Boron. In 'Methods of soil analysis: Part 2. Chemical and microbiological properties'. (Ed. AL Page) pp. 431-448. American Society of Agronomy: Madison, WI, USA.

Cakmak I, Pfeiffer WH and McClafferty B, 2010. Review: biofortification of durum wheat with zinc and iron. Cereal Chem. 87: 10-20.

Chapman HD and Pratt PF, 1961. Methods of analysis for soils, plants and water. University of California: Berkeley, CA, USA.

Ferdoush JN and Rahman MM, 2013. Effects of boron fertilization and sowing date on the grain protein content of wheat varieties. J. Environ. Sci. Nat. Resour. 6: 41-45.

Ganie MZ, Akhter F, Bhat MA, Malik AR, Mihd Junaid J, Shah MA, Bhat AH and Bhat TA, 2013. Boron- a critical nutrient element for plant growth and productivity with reference to temperate fruits. Curr. Sci. 104: 76-85.

George E, Rolf S and John R, 2013. Methods of Soil, Plant, and Water Analysis. A Manual for the West Asia and North Africa region. Aleppo, Syria: International Center for Agricultural 
Research in the Dry Areas.

Gümüş İ and Şeker C, 2015. Influence of humic acid applications on soil physicochemical properties. Solid Earth Dis. 7: 2481-2500.

Haghighi M, Kafi M and Fang P, 2012. Photosynthetic activity and $\mathrm{N}$ metabolism of lettuce as affected by humic acid. Int. J. Veg. Sci. 18(2): 182-189.

Hafeez BMKY and Saleem M, 2013. Role of zinc in plant nutrition- a review. Am. J. Exp. Agric. 3: 374-391.

Hassan N, Irshad S, Saddiq MS, Bashir S, Khan S, Wahid MA, Khan RR and Yousra M, 2019. Potential of Zinc Treatment in Improving Stand Establishment, Phenology, Yield and Grain Biofortification of Wheat. J. Plant Nutr. 42(14): 1676-1692.

Herrera-Rodriguez MB, Gonzalez-Fontes A, Rexach J, Camacho-Cristobal JJ, Maldonado JM and Navarro-Gochicao MT, 2010. Role of boron in vascular plants and response mechanism to boron stresses. Plant Stress. 4: 115-122.

Iqbal S, Farooq M, Cheema SA and Afzal I, 2017. Boron seed priming improves the seedling emergence, growth, grain yield and grain biofortification of bread wheat. Int. J. Agric. Biol. 19: 177-182.

Iqtidar A and Rehman SF, 1984. Effect of boron on the protein and amino acid composition of wheat grain. J. Agric. Sci. 103: 75-80.

Jackson ML, 1960. Soil analysis. Constable and Co Ltd., London.

Johnson SE, Lauren JG, Welch RM and Duxbury JM, 2005. A comparison of the effects of micronutrient seed priming and soil fertilization on the mineral nutrition of chickpea (Cicer arietinum), lentil (Lens culinaris), rice (Oryza sativa) and wheat (Triticum aestivum) in Nepal. Exp. Agri. 41: 427-448.

Khan R, Gurmani AH, Gurmani AR and Zia MS, 2006. Effect of boron on rice yield under wheatrice system. Int. J. Agric. Biol. 8: 805-808.

Khan S, Rehman HR, Wahid MA, Saleem MF, Cheema MA, Basra SMA and Nadeem M, 2016. Boron fertilization improves seed yield and harvest index of Camelina sativa $\mathrm{L}$. By affecting source-sink. J Plant Nutr. 39(12): 1681-1687.

Khattak RA, Haroon K and Muhammad D, 2013. Mechanism(s) of humic acid induced beneficial effects in salt affected soils. Sci. Res. Essay. 8:
932-939.

Kosina P, Reynolds M, Dixon J and Joshi A, 2007. Stakeholder perception of wheat production constraints, capacity building needs, and research partnerships in developing countries. Euphytica, 157: 475-483.

Marschener H, 1995. Boron. In Mineral nutrition of higher plants, ed. Horst Marschner, 2nd ed., 379396. San Diego: Academic Press.

Muscolo A, Sidari M and Nardi S, 2013. Humic substance: relationship between structure and activity. Deeper information suggests univocal findings. J. Geochem. Explor. 129: 57-63.

Pandey N, Pathak GC and Sharma CP, 2006. Zinc is critically required for pollen function and fertilisation in lentil. J. Trace Ele. Med. Bio. 20(2): 89-96.

Peña-Méndez EM, Havel J and Patočka J, 2005. Humic substances--compounds of still unknown structure: applications in agriculture, industry, environment, and biomedicine. J. Appl. Biomed. 3: $13-24$.

Radwan FI, Gomaa MA, Rehab IF and Samera IAA, 2015. Impact of humic acid application, foliar micronutrients and biofertilization on growth, productivity and quality of wheat (Triticum aestivum, L). Mid. East J. Agric. Res. 4(2): 130140.

Ramzan Y, Hafeez MB, Khan S, Nadeem M, Rahman SU, Batool S and Ahmad J, 2020. Biofortification with Zinc and Iron Improves the Grain Quality and Yield of Wheat Crop. Int. J. Plant Prod. 14(3): 501-510.

Rashid A, 1986. Mapping zinc fertility of soils using indicator plants and soils-analyses. $\mathrm{PhD}$ Dissertation, University of Hawaii, HI, USA.

Rashid A, Yasin M and Ashraf M, 2004. Boron deficiency in calcareous soil reduces rice yield and impairs grain quality. Int. Rice Res. Notes. 29: 58-60.

Rehman A, Farooq M, Naveed M, Nawaz A and Shahzad B, 2018. Seed priming of $\mathrm{Zn}$ with endophytic bacteria improves the productivity and grain biofortification of bread wheat. Eur. J. Agron. 94: 98-107.

Sharif M, Khattak RA and Sarir MS, 2002. Effect of different levels of lignitic coal derived humic acid on growth of maize plants. Commun. Soil Sci. Plant Anal. 33: 3567-3580. 
Soleimani R, 2006. The effects of integrated application of micronutrient on wheat in low organic carbon conditions of alkaline soils of western Iran. 18th World Congress of Soil Science.

Steel RGD, Torrie JH and Dickey D, 1997. Principles and Procedures of Statistics: A Biometric Approach, 3rd edition, pp: 663-666 McGrawHill Book Co., New York, NY, USA.

Tahir MM, Khurshid M, Khan MZ, Abbasi MK and Kazmi MH, 2011. Lignite-derived humic acid effect on growth of wheat plants in different soils. Pedosphere. 21(1): 124-131.

Zeidan MS, Manal F and Hamouda HA, 2010. Effect of foliar fertilization of $\mathrm{Fe}, \mathrm{Mn}$ and $\mathrm{Zn}$ on wheat yield and quality in low sandy soils fertility. World J. Agric. Sci. 6: 696-699.

\section{Contribution of Authors}

Hussan MU, Saleem MF \& Hafeez MB: Designed and conducted the experiment, collected \& analysed data and prepared the first draft Khan S: Analyzed the collected data and prepared first draft, submitted the final draft as a corresponding author Hussain S: Collected \& interpreted data Ahmad N, Ramzan Y \& Nadeem M: Helped in writing the manuscript and final draft preparation 